\title{
Analisis Pengujian Stabilitas dan Durabilitas Campuran Aspal dengan Tes Perendaman
}

\author{
*Haris ${ }^{1}$ \\ ${ }^{1}$ Program Studi Teknik Sipil, Fakultas Teknik, Universitas Madako, Tolitoli, Indonesia \\ haris.umada@gmail.com \\ *Alamat korespondensi, Masuk: 04 Des. 2019, Direvisi: 12 Jan. 2019, Diterima: 26 Jan. 2019
}

\begin{abstract}
ABSTRAK: Dampak dari curah hujan yang cukup tinggi, di tambah lagi dengan beban lalu lintas yang tidak terkendali, maka sangat perlu di lakukan penelitian tentang analisis pemanfaatan bahan alam kapur padam, sebagai pemenuhan bahan pengisi (Filler) dengan tujuan untuk meningkatkan kinerja, kekuatan, ketahanan ,stabilitas dan durabilitas campuran AC-WC gradasi halus. Penelitian ini dilakukan dengan 5 variasi campuran, hasil pengujian variasi 1, 2, 3, 4 dan 5 secara berurutan dengan nilai KAO: 5,7\%; 6,3\%; 6,6\%; 6,8\%; dan 7,2\%. Nilai karakteristik Marshall meliputi stabilitas, flow dan MQ yaitu variasi 1 (1221 $\mathrm{kg}, 4,7 \mathrm{~mm}, 263 \mathrm{~kg} / \mathrm{mm})$, variasi $2(1346 \mathrm{~kg}, 4,2 \mathrm{~mm}, 320 \mathrm{~kg} / \mathrm{mm})$, variasi $3(1361 \mathrm{~kg}, 3,7 \mathrm{~mm}, 373 \mathrm{~kg} / \mathrm{mm})$, variasi $4(1434 \mathrm{~kg}, 3,4 \mathrm{~mm}, 417 \mathrm{~kg} / \mathrm{mm})$ dan variasi $5(1533 \mathrm{~kg}, 3,2 \mathrm{~mm}, 479 \mathrm{~kg} / \mathrm{mm})$. Nilai IDP mulai dari campuran variasi 1 (100\% debu batu) mengalami kehilangan kekuatan (r) total sebesar 0,64\%, dan campuran variasi 2 (75\% debu batu) dengan (r) total 0,87\%, campuran variasi 3 (50\% kapur padam) dengan (r) total 0,48\% dan campuran variasi 4 (75\% kapur padam) dengan (r) total 0,52\%, kemudian campuran variasi 5 (100\% kapur, padam). Dari hasil penelitian menunjukkan bahwa campuran variasi 3 dan campuran variasi 4 dengan KAO 6,6\% dan 6,8\%, mempunyai nilai indeks kekuatan sisa dn indeks durabilitas yang paling baik.
\end{abstract}

Kata kunci: Campuran aspal, Stabilitas, Durabilitas, Marshaal perendaman

\begin{abstract}
The impact of from the high rainfall, in More again with the traffic loads uncontrollable, Then it is very necessary to do research on the analysis of the utilization of natural materials lime distinguished, as the fulfillment of filler, with the purpose to improve the performance, strength, durability, stability, and durability the mixture AC-WC fine gradation. This research was conducted with 5 mixed variations, variation test results $1,2,3,4$ and 5 respectively with $\mathrm{KAO}$ values, $5.7 \%, 6.3 \%, 6.6 \%, 6.8 \%$, and $7.2 \%$. Marshall characteristic values include stability, flow and MQ namely variation $1(1221 \mathrm{~kg}, 4.7 \mathrm{~mm}$, $263 \mathrm{~kg} / \mathrm{mm})$, variation $2(1346 \mathrm{~kg}, 4.2 \mathrm{~mm}, 320 \mathrm{~kg} / \mathrm{mm})$, variation $3(1362 \mathrm{~kg}, 3.7 \mathrm{~mm}, 373 \mathrm{~kg} / \mathrm{mm})$, variation $4(1434 \mathrm{~kg}, 3.4 \mathrm{~mm}, 417 \mathrm{~kg} / \mathrm{mm})$ and variation $5(1533 \mathrm{~kg}, 3.2 \mathrm{~mm}, 479 \mathrm{~kg} / \mathrm{mm})$. IDP values began to form a mixture of variation 1 (100\% stone dust) suffered a lose strength (r) a total of $0.64 \%$, and a mixture of variation 2 ( $75 \%$ stone dust) to (r) a total of $0.87 \%$, a mixture of variation 3 ( $50 \%$ hydrated lime) with (r) total variation mixture $0.48 \%$ and mixture of variations 4 ( $75 \%$ hydrated lime) with (r) total of $0.52 \%$, fromThe results of the study showed that mixture of variation 3 and 4 with $\mathrm{KAO}, 6.6 \%$, and $6.8 \%$ had the value stability, durability.
\end{abstract}

Keywords: Asphalt mixture, Stability, Durability, Imersion marshall

\section{PENDAHULUAN \\ Latar Belakang}

Seiring dengan laju pertumbuhan penduduk di suatu daerah, maka jalan raya sebagai bagian prasarana transportasi mempunyai peran penting dalam penunjang aktivitas masyarakat. Pentingnya peranan jalan tersebut disebabkan jalan merupakan salah satu penggerak roda perekonomian di berbagai sektor pembangunan daerah yang dibangun dan dipergunakan untuk kepentingan masyarakat luas. Oleh karena itu, sesuai dengan perkembangan teknologi sarana transportasi, maka dibutuhkan prasarana jalan yang memadai diantaranya adalah jenis konstruksi jalan, baik geometrik maupun struktur perkerasan (pavement). Jalan yang aman, nyaman, kuat, awet, serta ekonomis akan mempermudah manusia dalam proses pergerakannya. Kapur padam berfungsi sebagai bahan pengisi (filler) juga dapat berfungsi sebagai bahan anti-stripping agent yang dapat meningkatkan durabilitas atau keawetan kinerja 
campuran beton aspal dalam menerima repetisi beban lalu lintas seperti berat kendaraan dan gesekan antara roda kendaraan dan permukaan jalan, serta menahan keausan akibat pengaruh cuaca dan iklim seperti udara, air, atau perubahan temperatur.

Dengan demikian untuk mewujudkan kondisi jalan yang berkualitas maka perlu diberikan teknologi penanganan yang benilai ekonomis (Social Cost), yaitu salah satu alternatif adalah memberikan bahan pengisi (filler) yang dapat digunakan dalam campuran beton aspal yaitu kapur padam (hydrated lime), karena disamping harganya relatif murah kapur padam juga merupakan material bahan tambah lokal yang banyak terdapat di Sulawesi Tengah. Diharapkan dapat diperoleh peningkatan nilai stabilitas dan durabilitas pada campuran $\mathrm{AC}-\mathrm{WC}$ gradasi halus.

\section{Tujuan Penelitian}

Mengetahui komposisi campuran AC-WC, dengan menggunakan bahan alam kapur padam dan debu batu, pasir alam serta agregat sungai Tinigi Tolitoli, sehingga dapat di ketahui Kadar Aspal Optimum ( KAO ).

Mengetahui Karakteristik campuran dengan pemanfaatan agregat sungai di kabupaten Tolitol, seperti bahan alam Kapur padam,dan Debu batu dengan variasi $(100 \% \mathrm{DB}-0 \% \mathrm{KP}),(75 \% \mathrm{DB}-25$ $\% \mathrm{KP}),(50 \% \mathrm{DB}-50 \% \mathrm{KP}),(75 \% \mathrm{KP}-25 \% \mathrm{DB})$, $(100 \% \mathrm{KP}-0 \% \mathrm{DB})$, pada persentase berat total filler agregat campuran aspal $\mathrm{AC}-\mathrm{WC}$, yang meliputi karakteristik marshall seperti, Stabilitas, kelelehan (Flow), VMA (Void in mineral aggregate), VITM (Void in the mix) dan MQ (Marshall Qoutient).

Mengetahui tingkat keawetan (durabilitas) dan ketahanan (stabilitas) campuran terhadap pengaruh air dan temperatur dalam waktu lama, dengan memanfaatkan kapur padam, debu batu, pasir alam serta agregat kasar dari sungai Tinigi Kabupaten Tolitoli (Uji durabilitas 1, 2, 4, 7 hari ) pada kadar aspal optimum ( KAO )

\section{Manfaat Penelitian}

Pemanfaatan bahan alam kapur padam sebagai (Filler) serta pasir alam yang deposit sangat melimpah di kabupaten Tolitoli Provinsi Sulawesi Tengah, sebagai salah satu upaya pemanfaatan secara maksimal potensi alam, sehingga akan sangat bermanfaat bagi peningkatan produksi pada masyarakat serta perusahaan Tambang yang ada di area tersebut.
Dapat juga bermanfaat sebagai pilihan yang sifatnya Alternatif sebagai masukan dalam bidang ilmu rekayasa jalan terutama bagi pemerintah daerah Kabupaten Tolitoli, Sulawesi Tengah yaitu Dinas Pekerjaan Umum Kabupaten dan perencana, pelaksana konstruksi yang selama ini mengalami kesulitan dalam menyediakan bahan Pengisi (Filler) dalam jumlah yang cukup.

\section{Batasan Penelitian}

Pencampuran menggunakan rancangan spesifikasi umum bina marga, divisi VI Perkerasan Aspal Dep. PU Edisi Tahun 2010 Revisi II yang di keluarkan oleh Direktorat Jenderal Bina Marga Republik Indonesia.

Asal material agregat kasar dan halus seperti pasir alam yang berasal dari sungai tinigi, Kabupaten Tolitoli Propinsi Sulawesi Tengah.

Kapur Padam sebagai bahan pengisi (Filler) berasal dari daerah tondo Kec.Palu Timur Propinsi Sulawesi Tengah.

Debu batu, sebagai bahan pengisi (Filler) berasal dari daerah sungai Tinigi Kabupaten Tolitoli Propinsi Sulawesi Tengah.

Aspal minyak pen. 60/70 produksi pertamina.

Dalam pembahasan tidak mengurai secara mendalam mengenai kandungan kimiawi aspal maupun kapur padam serta ikatannya, hanya pengaruh umum yang berkaitan dengan struktur perkerasan aspal.

\section{TINJAUAN PUSTAKA Kapur (lime)}

Merupakan salah satu mineral industri yang banyak digunakan oleh sektor industri maupun konstruksi, secara umum kapur bersifat hidrolis tidak menunjukkan pelapukan dan dapat terbawa arus. Secara fisik kapur merupakan sebuah benda putih yang halus dengan bahan dasar adalah batu kapur. Batu kapur mengandung kalsium karbonat $\mathrm{CaCO} 3$, dengan pemanasan $\left( \pm 980^{\circ} \mathrm{C}\right)$ karbon dioksidanya keluar dan tinggal kapurnya saja $(\mathrm{CaO})$. Kapur dari hasil pembakaran ini bila ditambahkan air akan mengambang dan retak, banyak panas yang dikeluarkan (seperti mendidih) selama proses ini dan hasilnya ialah "Calsium Hydroksida" $\mathrm{Ca}(\mathrm{OH}) 2$. Air yang dipakai untuk proses ini secara teoritis diperlukan hanya $32 \%$ berat kapur, akan tetapi karena faktor-faktor antara lain seperti pembakaran, jenis kapur dan sebagainya kadang-kadang air yang diperlukan sampai 2 atau 3 kali volume kapur proses ini disebut "slaking" adapun sebagian hasilnya yaitu kalsium hidroksida yang disebut "slaked lime atau hydrated lime". 
Brown et al. [1] menyatakan bahwa kapur adalah suatu material hasil perubahan batu kapur (Lime Stone) melalui proses pembakaran dengan suhu $850 \mathrm{C}$ pada suhu tungku (tanur) batu kapur setelah pembakaran dapat dibedakan menjadi dua jenis yaitu: a) kapur tohor (Quicklim) yaitu telah melepaskan $\mathrm{CO}_{2}$ pada proses pembakaran; b) kapur padam (Hydrated lime) yaitu hasil dari perubahan kapur tohor setelah penambahan air menjadi hydrat kapur.

Peristiwa terbentuknya $\mathrm{Ca}(\mathrm{OH}) 2$ ini disebut proses pemadaman diiringi pengeluaran panas dimana panas yang di keluarkan ini berguna sekali untuk pemadaman kapur sehingga $\mathrm{Ca}(\mathrm{OH}) 2$ ini yang disebut dengan kapur padam. Penggunaan kapur padam pada campuran beraspal sebagai filler dapat memperbaiki keawetan campuran dan membantu penyelimutan partikel agregat dengan aspal serta membantu mencegah pengelupasan.

Roberts et al. [2] mengatakan bahwa, pemakaian kapur pada campuran beton aspal sebagai Filler dapat memperbaiki sifat kelelahan (Fatique) dan meningkatkan Ketahanan terhadap terjadinya alur ( rutting).

\section{Debu Batu (Stone dust)}

Sukirman [3] Mineral filler abu batu merupakan hasil produksi pemecah batu Stone crusher yang lolos saringan no. 200. Filler abu batu pada umumnya yang paling sering digunakan pada perkerasan jalan raya. Kualitas abu batu sangat tergantung dari kualitas bahannya, bahan abu batu khususnya batu kali idealnya bahan abu batu yang dipakai adalah hasil dari batuan yang keras dan kuat, karakteristik Abu Batu yaitu: a) Berasal dari magma yang keluar ke permukaan bumi kemudian mendingin dan membeku; b) Termasuk batuan beku; c) Terdapat didaerah sungai dan gunung berapi; d) Berwarna abu-abu kehitaman; e) Memiliki tingkat kekerasan skala Mohs 7-8 (dari 10 tingkat kekerasan)

\section{Beton Aspal}

Asphalt Institute [4] menyatakan beton aspal banyak digunakan sebagai lapis permukaan untuk jalan yang menerima beban lalu lintas yang tinggi yang tersusun dari agregat dengan gradasi menerus dan bahan ikat aspal yang diolah dan dicampur secara panas.

Wibowo [5] beton aspal merupakan jenis campuran bahan jalan yang terdiri dari campuran aspal keras dan agregat yang mempunyai gradasi menerus, dicampur dihamparkan dan dipadatkan pada suhu tertentu. Agregatnya terdiri dari agregat kasar, agregat halus, filler yang bergradasi baik. Sedangkan gradasi menerus adalah suatu komposisi yang menunjukkan pembagian butiran agregat merata mulai dari ukuran yang terbesar sampai yang terkecil.

\section{AC- Wearing Course.}

Sukarman [6] beton aspal untuk lapis permukaan (AC-WC), adalah lapisan yang terletak di atas permukaan aspal atau sebagai lapisan Aus. yang berhubungan langsung dengan cuaca dan temperatur sehingga perlu memiliki stabilitas yang baik untuk memikul beban lalu lintas yang dilimpahkan melalui roda kendaraan. Lapis permukaan (Wearing Course) mempunyai fungsi: a) Mengurangi tegangan/regangan akibat beban lalu lintas dan meneruskannya kelapisan dibawahnya harus mempunyai ketebalan dan kekakuan cukup; b) Mempunyai kekuatan yang tinggi pada bagian perkerasan untuk menahan beban paling tinggi, akibat beban lalu lintas.

Beton aspal (Asphalt Concrete) ini di Indonesia dikenal dengan sebutan laston (Lapisan Aspal Beton), adalah beton aspal bergradasi menerus yang umum digunakan untuk jalan-jalan dengan beban lalu lintas berat. Karakteristik beton aspal yang terpenting dalam campuran ini adalah stabilitas, tebal nominal minimum laston 4-6 cm. Laston Sebagai bahan pengikat, dikenal dengan nama AC-W C (Asphalt Concrete - Wearing Course), tebal nominal minimum $\mathrm{AC}-\mathrm{WC}$ adalah 4 $\mathrm{cm}$.

\section{Aspal Keras Pen.60/70}

Kementerian Pekerjaan Umum Direktorat Jenderal Bina Marga [7] menyatakan bahan aspal untuk campuran beton aspal harus salah satu dari jenis Aspal Keras Pen.60/70, Aspal Polimer, Aspal Modifikasi dengan Asbuton dan Aspal Multigrade yang memenuhi persyaratan. AASHTO [8] menyatakan jenis aspal keras ditandai dengan angka penetrasi aspal, angka tersebut menyatakan tingkat kekerasan aspal atau tingkat konsistensi aspal, semakin besar angka penetrasi aspal tingkat kekerasan aspal semakin rendah (aspal semakin buruk), sebaliknya semakin kecil angka penetrasi aspal tersebut maka tingkat kekerasan aspal semakin tinggi (aspal semakin semi padat atau padat).

\section{Metode Marshall}

Domel et al. [9] Metode pengujian Marshall merupakan metode yang paling umum dipergunakan dan distandarisasikan dalam Ashley 
et al. [10]. Dalam metode tersebut terdapat 3 parameter penting dalam pengujian tersebut, yaitu beban maksimum yang dapat dipikul benda uji sebelum hancur atau sering disebut dengan Marshall Stability dan deformasi permanen dari benda uji sebelum hancur yang disebut dengan Marshall Flow serta turunan yang merupakan perbandingan antara keduannya (Marshall Stability dengan Marshall Flow) yang disebut dengan Marshall Quotient (MQ). MQ merupakan nilai kekakuan berkembang (Speedo Stiffness), yang menunjukkan ketahanan campuran beton aspal terhadap deformasi tetap (permanen).

Miller et al. [11], bahwa dua sifat yang diperoleh dengan menggunakan metode marshall adalah stabilitas dan kelelehan. Melalui metode marshall juga diperoleh analisa rongga yang dilakukan dengan pengukuran terhadap benda uji dan menghasilkan parameter-parameter seperti kepadatan (density), VMA (void in mineral agregate), VITM (void in the mix),VFWA (void filled with asphalt), nilai stabilitas dan kelelehan (flow), dan MQ (Marshall Quotient) merupakan hasil bagi antara nilai stabilitas dan kelelehan. Nilai MQ dipakai sebagai pendekatan terhadap tingkat kekakuan dan fleksibilitas campuran.

\section{Durabilitas}

Suparma [12] durabilitas (awet) yaitu ketahanan terhadap cuaca/iklim, pelapukan dan perusakan dari beban roda kendaraan yang masuk dalam "Durabel" (tahan dan awet). Tahan terhadap pengaruh oksidasi dan suhu udara tahan terhadap aksi perusakan air, tidak mudah pecah / kokoh akibat tumbukan roda ("resistance to brittle cracking').

Aspalt Institute [4] durabilitas adalah kemampuan atau daya tahan suatu perkerasan terhadap beberapa faktor seperti perubahan perubahan dalam bitumen yang di sebabkan oleh oksidasi, disintegrasi agregat, dan pelepasan lapisan - lapisan bitumen dari agregat akibat kondisi basah dan beban lalu lintas. Durabilitas berkaitan dengan keawetan campuran terhadap pengaruh air dan temperatur dalam waktu lama. Campuran harus tahan terhadap air dan perubahan sifat aspal karena penguapan dan oksidasi. Durabilitas campuran perkerasan di tentukan: a) Pemilihan bahan susun yang baik dan sesuai dengan persyaratan; b) Komposisi bahan susun sesuai dengan persyaratan; c) Kekuatan sesuai dengan perencanaan; d) Pelaksanaan pekerjaan yang baik; e) Perawatan.

Miller et al. [11], mendefinisikan bahwa durabilitas adalah ketahanan campuran terhadap faktor penyebab kerusakan, diantaranya adalah proses penuaan aspal, terjadi pemisahan antar agregat, dan pelepasan lapis tipis aspal dari agregat. Pada umumnya durabilitas campuran dapat di tingkatkan dengan cara: menggunakan jenis campuran dengan gradasi rapat (dense gradation) ketebalan lapis tipis aspal yang cukup pada agregat dan pemadatan campuran di lapangan hingga rongga dalam campuran kurang dari $8 \%$.

\section{Stabilitas Campuran Beton Aspal}

Miller et al. [11] Stabilitas adalah kemampuan perkerasan jalan untuk tidak mengalami deformasi berlebihan selama melayani kendaraan yang lewat. Stabilitas campuran tergantung pada gaya gesek internal dan kohesitas. Gaya gesek antar butir-butir agregat berhubungan dengan sifat agregat seperti gradasi, bentuk dan tekstur permukaan, sedangkan kohesitas merupakan gaya ikat yang di miliki aspal dan di pengaruhi oleh tipe dan jumlah bahan pengisi yang di tambahkan. Daya ikat dan gaya gesek akan menahan perpindahan antar butiran agregat akibat beban lalu lintas.

Menurut Bahia et al. [13] pengujian tingkat durabilitas campuran pada umumnya dilakukan dengan pengujian perendaman Marshall (Marshall Imersion test), yang dinyatakan dengan suatu parameter yang di namakan Retained Marshall Stability (RMS) yaitu membandingkan kekuatan stabilitas benda uji setelah di kondisikan pada suhu $60{ }^{\circ} \mathrm{C}$ selama 24 jam dengan stabilitas benda uji rendaman standar.

\section{Durabilitas Modifikasi}

Rahim et al. [14] Mengembangkan parameter tunggal yang dapat menggambarkan kondisi keawetan suatu campuran beraspal panas, setelah melalui serangkaian periode perendaman tertentu. Parameter ini dinamakan Indeks Keawetan yang terdiri dari dua jenis, yaitu indeks keawetan pertama dan indeks keawetan kedua. Dalam metode ini dilakukan lama perendaman yaitu 1/2, 24 dan 48 jam.

\section{Indeks Durabilitas Pertama (IDP)}

Indeks Durabilitas Pertama dapat dihitung dengan menggunakan persamaan sebagai berikut:

$r=\sum_{i-1}^{n-1}=\frac{S_{i}-S_{i+1}}{t_{i+1-t_{i}}}$

Di mana: $\mathrm{r}=$ Indeks Penurunan Stabilitas (\%); $\mathrm{Si}+1$ $=$ persentase kekuatan sisa pada waktu ti $+1 ; \mathrm{Si}=$ persentase kekuatan sisa pada waktu ti; ti , ti $+1=$ periode perendaman (dimulai dari awal pengujian). 
Nilai ' $r$ ' yang positif mengindikasikan kehilangan kekuatan, sedangkan nilai ' $r$ ' negatif mengindikasikan adanya perolehan kekuatan.

$r=\frac{1}{t_{n}} \sum_{i=0}^{n} a_{i}=\frac{1}{2 t_{i}} \sum_{i=0}^{n-1}\left(S_{i}-S_{i+1}\right)\left[2 t_{n}-\left(t_{i}+\right.\right.$ $\left.\left.t_{i+1}\right)\right]$

Di mana: $\mathrm{Si}+1=$ persentase kekuatan sisa pada waktu ti $+1 ; \mathrm{Si}=$ persentase kekuatan sisa pada waktu ti; $\mathrm{ti}, \mathrm{ti}+1=$ periode perendaman (dimulai dari awal pengujian); $\mathrm{tn}=$ total waktu perendaman.

Indeks durabilitas ini menggambarkan kehilangan kekuatan satu hari. Nilai 'a' positif menggambarkan kehilangan kekuatan, sedangkan nilai 'a' negatif merupakan pertambahan kekuatan. Berdasarkan definisi tersebut, maka nilai a $<100$. Oleh karena itu, memungkinkan untuk menyatakan persentase ekuivalen kekuatan sisa satu hari.

\section{LANDASAN TEORI}

\section{Agregat yang Digunakan}

Agregat kasar dan agregat halus yang digunakan dalam penelitian harus bebas dari kotoran, bahan organik atau bahan lain yang tidak dikehendaki serta kualitasnya harus memenuhi persyaratan mutu.

\section{Filler yang digunakan}

Bahan pengisi (Filler) termasuk debu batu (stone dust) yang ditambahkan harus kering dan bebas dari gumpalan dan bila di uji dengan pengayaan sesuai SNI 03-6723-2002 [15] harus mengandung bahan yang lolos ayakan No. 200 (75 micron) tidak kurang dari $75 \%$ terhadap beratnya dan mempunyai sifat non plastis. Filler juga berpengaruh terhadap kadar aspal optimum melalui luas permukaan dari partikel mineralnya, sehingga sifat - sifat permukaan partikel Filler akan memodifikasi sifat reologi aspal, diantaranya terhadap penetrasi, daktilitas dan ketahanan campuran terhadap retak. Di samping itu jenis dan jumlah filler yang di gunakan juga akan mempengaruhi kualitas dari mortar.

\section{Sifat Campuran Laston}

Beton aspal adalah jenis perkerasan jalan yang terdiri dari campuran agregat kasar, agregat halus, bahan pengisi (filler), dan aspal sebagai bahan pengikat [3]. Menurut spesifikasi baru campuran beraspal Kementerian Pekerjaan Umum 2010 [16], Laston (AC) terdiri dari tiga macam campuran, AC Lapis Aus (AC-WC), AC Lapis Antara (AC-BC), dan AC Lapis Pondasi (AC-Base). Beton Aspal
Lapis Aus adalah merupakan lapisan paling atas dari struktur perkerasan.

\section{Aspal yang di Gunakan}

Aspal keras yang digunakan sebagai bahan pengikat pada penelitian ini, berupa aspal keras AC Pen. $60 / 70$ yang mempunyai spesifikasi teknis yang telah disesuaikan dengan kondisi alam Indonesia. Persyaratan yang harus dipenuhi untuk penggunaan jenis aspal keras (asphalt cement) yaitu berdasarkan pada spesifikasi 2010 ( Revisi.2 ) Departemen Pekerjaan Umum.

\section{Lapis Permukaan Perkerasan}

Lapisan perkerasan lentur adalah perkerasan yang menggunakan aspal sebagai bahan ikatanya. Lapisan permukaan pada perkerasan ini berfungsi untuk mendukung beban dan menyebarkan kedalam tanah dasar. Campuran panas aspal dan agregat yang digunakan untuk bahan lapis permukaan perkerasan lentur, harus mampu mendukung fungsi dari lapis permukaan itu. (Totomihardjo,1994),

Metode perencanaan tebal perkerasan lentur jalan baru umunnya dapat dibedakan atas 2 metode yaitu: 1) Metode empiris, metode ini dikembangkan berdasarkan pengalaman dan penelitian dari jalan jalan yang dibuat khusus untuk penelitian atau dari jalan yang sudah ada; 2) Metode Teoritis, metode ini dikembangkan berdasarkan teori matematis dari sifat tegangan dan regangan pada lapisan perkerasan akibat beban berulang dari lalu lintas. (Alamsyah, 2006)

\section{Gradasi Agregat Gabungan}

Departemen PU (2005) manyatakan gradasi agregat gabungan untukcampuran aspal harus memenuhi batas - batas dan harus berada di luar daerah larangan (Restriction Zone). Gradasi atau juga disebut partikel-partikel berdasarkan ukuran agregat merupakan hal yang penting dalam menentukan sifat karakteristik perkerasan. Gradasi agregat menentukan besarnya rongga atau pori yang mungkin terjadi dalam campuran. Agregat campuran yang terdiri dari agregat berukuran sama akan berongga atau berpori banyak, karena tak terdapat agregat berukuran lebih kecil yang dapat mengisi rongga yang terjadi. Sebaliknya jika campuran agregat terdistribusi dari agregat berukuran besar sampai kecil merata, maka rongga atau pori yang terjadi sedikit. Hal ini disebabkan karena rongga yang terbentuk oleh susunan agregat berukuran besar, akan diisi oleh agregat berukuran lebih kecil (Sukirman, 2003) 


\section{METODE PENELITIAN \\ Umum}

Penelitian ini dilaksanakan di Laboratorium Teknik Transportasi Fakultas Teknik Jurusan Teknik Sipil Univesitas Gadjah Mada Yogyakarta, dengan dasar menggunakan sistem pencampuran aspal panas Asphalt Concrete - Wearing Course (AC-WC). Sedangkan standar-standar pengujian yang digunakan adalah spesifikasi Pekerjaan Umum bina marga tahun 2010 (Revisi, 2) [16], serta sebagian menggunakan standar yang dikeluarkan oleh The Asphalt Institute (1997) Superpave Series No.1 (SP1) namun juga sebagian mengadopsi dari metodemetode yang disahkan atau distandarkan oleh Bina Marga yang berupa SK- SNI.

\section{Prosedur Penelitian}

Metode penelitian disusun untuk memberikan kemudahan dalam pelaksanaan sebuah penelitian sehingga berjalan lebih tepat efektif dan efisien. Tahapan prosedur pelaksanaan ini tergambar dalam suatu bagan alir metode penelitian. Adapun langkah-langkah yang akan dilakukan dalam melaksanakan penelitian ini dapat dilihat pada gambar bagan alir penelitian. Untuk menentukan kadar aspal optimum diperkirakan dengan penentuan kadar optimum secara empiris dengan persamaan $(\mathrm{Pb})$. Nilai $\mathrm{Pb}$ hasil perhitungan dibulatkan mendekati $0,5 \%$. Ditentukan 2 (dua) kadar aspal di atas dan 2 (dua) kadar aspal di bawah kadar aspal perkiraan awal yang sudah dibulatkan mendekati $0,5 \%$ ini. Kemudian dilakukan penyiapan benda uji untuk tes Marshall sesuai tahapan berikut ini :

Tahap pertama, berdasarkan perkiraan kadar aspal optimum $\mathrm{Pb}$ dibuat benda uji dengan jenis aspal Pertamina Pen. 60/70, dengan dua variasi kadar aspal di atas $\mathrm{Pb}$ dan dua variasi kadar aspal di bawah $\mathrm{Pb}(-1,0 \% ;-0,5 \% ; \mathrm{Pb} ;+0,5 \% ;+1,0 \%)$ serta variasi komposisi Filler dengan dibuat masingmasing 3 (tiga) benda uji. Untuk variasi komposisi kadar filler adalah variasi 1, (100\% debu batu), variasi 2 (75\% debu batu),variasi 3 (50\% debu batu - 50\% kapur padam), variasi 4 (75\% kapur padam),dan variasi 5 (100\% kapur padam). Kemudian dilakukan pengujian Marshall standar dengan 2x75 tumbukan dan pengujian durabilitas untuk menentukan VIM, VMA, VFA, kepadatan, stabilitas, kelelehan, hasil bagi Marshall dan indeks stabilitas sisa. Dari hubungan antara kadar aspal dengan parameter Marshall, dapat ditentukan kadar aspal optimum (KAO)

Tahap kedua, setelah didapatkan kadar aspal optimum (KAO), maka dilakukan pembuatan benda uji dengan variasi komposisi filler yaitu variasi 1 (100\% debu batu), variasi 2 (75\% debu batu), variasi 3(50\% debu batu - 50\% kapur padam), variasi 4 (75\% kapur padam), dan variasi 5 (100\% kapur padam), pada durasi perendaman 1/2, 24 jam, 48 jam, 96 jam, dan 168 jam. Kemudian dilakukan uji Marshall dengan kondisi stadar (2x75 tumbukan) untuk menentukan VIM, VMA, VFA, kepadatan, stabilitas, kelelehan dan hasil bagi Marshall, serta pengujian durabilitas standar dan durabilitas modifikasi untuk menentukan nilai indeks durabilitas pertama (r, R) dan nilai indeks durabilitas kedua (a, Sa)

\section{HASIL DAN PEMBAHASAN Hasil Pengujian Agregat}

Agregat kasar dan agregat halus serta debu batu yang dipergunakan dalam penelitian ini berasal dari sungai Tinigi Kabupaten Tolitoli Sulawesi Tengah. Sedangkan bahan pengisi Filler menggunakan kapur padam asal daerah Tondo Palu utara Sulawesi Tengah. Hasil pengujian terhadap agregat kasar dan agregat halus dan serta bahan pengisi filler terdapat pada table. 1, 2 dan 3 .

Tabel 1. Hasil pengujian agregat kasar

\begin{tabular}{clcc}
\hline No. & Jenis Pengujian & Spesifikasi & Hasil \\
\hline 1 & $\begin{array}{l}\text { Keausan dengan } \\
\text { mesin los ageless (\%) }\end{array}$ & Maks. 40 & 25.10 \\
\hline 2 & $\begin{array}{l}\text { Kelekatan Agregat } \\
\text { terhadap Aspal (\%) }\end{array}$ & Min. 95 & 97.5 \\
\hline 3 & Berat Jenis ( gr/cc) & Min. 95 & 2.683 \\
\hline 4 & Berat Jenis Semu & Min. 2.5 & 2.733 \\
\hline 5 & Penyerapan air (\%) & Maks. 3 & 0.677 \\
\hline
\end{tabular}

Tabel 2. Hasil pengujian agregat halus

\begin{tabular}{clcc}
\hline No. & Jenis Pengujian & Spesifikasi & Hasil \\
\hline 1 & Sand equivalent (\%) & Min.60 & 95,12 \\
\hline 2 & $\begin{array}{l}\text { Kelekatan Agregat } \\
\text { terhadap aspal ( \% ) }\end{array}$ & Min. 95 & 97,5 \\
\hline 4 & Berat jenis (Bulk)( gr/cc ) & Min.2.5 & 2,684 \\
\hline 5 & Angularitas (\%) & Min.40 & 90,50 \\
\hline 6 & Penyerapan air (\%) & Maks. 3 & 1,210 \\
\hline
\end{tabular}

Tabel 3. Hasil pengujian bahan pengisi (Debu Batu)

\begin{tabular}{clcc}
\hline No. & Jenis Pengujian & Spesifikasi & Hasil \\
\hline 1 & Berat jenis ( gr/cc ) & Min.2.5 & 2,612 \\
\hline 2 & Lolos saringan no.200 (\% ) & Min.75 & 89,5 \\
\hline
\end{tabular}


Tabel 4. Hasil pengujian bahan pengisi (kapur padam)

\begin{tabular}{clcc}
\hline No. & Jenis Pengujian & Spesifikasi & Hasil \\
\hline 1 & Berat jenis semu ( gr/cc $)$ & - & 2,140 \\
\hline 2 & Lolos saringan no.200 $(\%)$ & Min.75 & 95,2 \\
\hline
\end{tabular}

Tabel 5. Hasil pengujian aspal Pen.60/70

\begin{tabular}{llccc}
\hline No & $\begin{array}{l}\text { Jenis } \\
\text { Pengujian }\end{array}$ & Spesifikasi & Hasil & Keterangan \\
\hline 1 & Berat Jenis & $\geq 1.0$ & 1,04 & Memenuhi \\
\hline 2 & $\begin{array}{l}\text { Daktilitas pada } \\
25^{\circ} \mathrm{C}(\mathrm{cm})\end{array}$ & $\geq 100$ & 100 & Memenuhi \\
\hline 3 & $\begin{array}{l}\text { Titik Lembek } \\
{ }^{\circ} \mathrm{C}\end{array}$ & $\geq 48$ & 48,5 & Memenuhi \\
\hline 4 & $\begin{array}{l}\text { Viskositas } \\
135^{\circ} \mathrm{C}\end{array}$ & & & \\
\hline 5 & $\begin{array}{l}\text { Penetrasi } 25^{\circ} \mathrm{C} \\
(0.1 \mathrm{~mm})\end{array}$ & $60-70$ & 67,6 & Memenuhi \\
\hline 6 & Titik Nyala ${ }^{\circ} \mathrm{C}$ & $\geq 232$ & 346 & Memenuhi \\
\hline 7 & $\begin{array}{l}\text { Penetrasi } \\
\text { setelah } \\
\text { kehilangan } \\
\text { berat (\% asli) }\end{array}$ & $\geq 54$ & 81,6 & Memenuhi \\
\hline
\end{tabular}

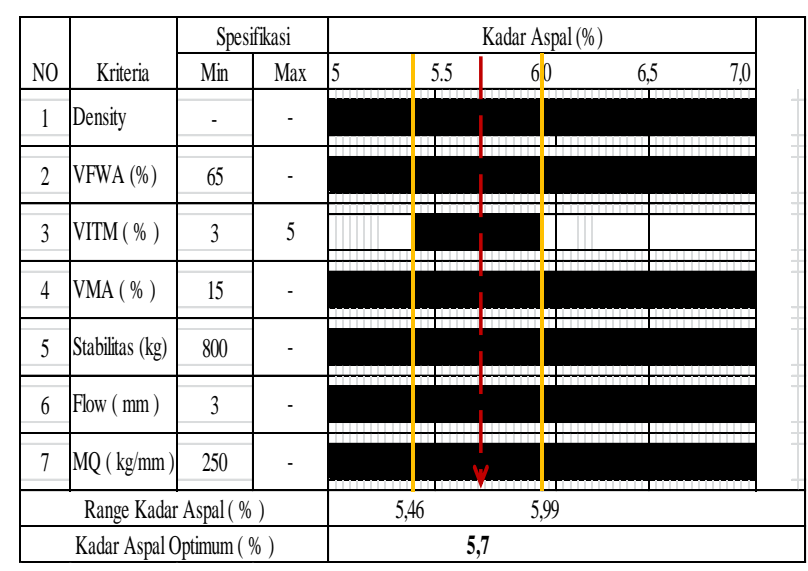

Gambar 1. Kadar aspal optimum (KAO) metode narrow range variasi 1

\begin{tabular}{|c|c|c|c|c|c|c|c|}
\hline \multirow[b]{2}{*}{ NO } & \multirow[b]{2}{*}{ Kriteria } & \multicolumn{2}{|c|}{ Spesifikasi } & \multicolumn{4}{|c|}{ Kadar Aspal (\%) } \\
\hline & & Min & Max & 5,5 & 6,0 & 6,5 & 7,0 \\
\hline 1 & Density & - & - & & & & \\
\hline 2 & VFWA $(\%)$ & 65 & - & & & & \\
\hline 3 & $\operatorname{VITM}(\%)$ & 3 & 5 & & & & \\
\hline 4 & $\operatorname{VMA}(\%)$ & 15 & - & & & & \\
\hline 5 & Stabilitas $(\mathrm{kg})$ & 800 & - & & & & \\
\hline 6 & Flow ( $\mathrm{mm}$ ) & 3 & - & & & & \\
\hline 7 & $\mathrm{MQ}(\mathrm{kg} / \mathrm{mm})$ & 250 & - & & & & \\
\hline & Range Kada & Aspal ( & & & 90 & & \\
\hline & Kadar Aspal & timum & & & & 0,0 & \\
\hline
\end{tabular}

Gambar 2. Kadar aspal optimum (KAO) metode narrow range variasi 2

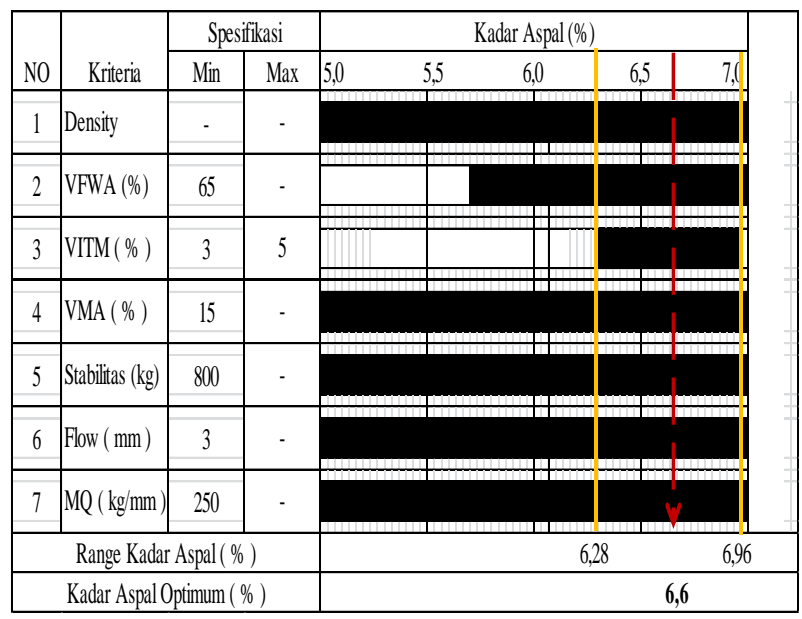

Gambar 3. Kadar aspal optimum (KAO) metode narrow range variasi 3

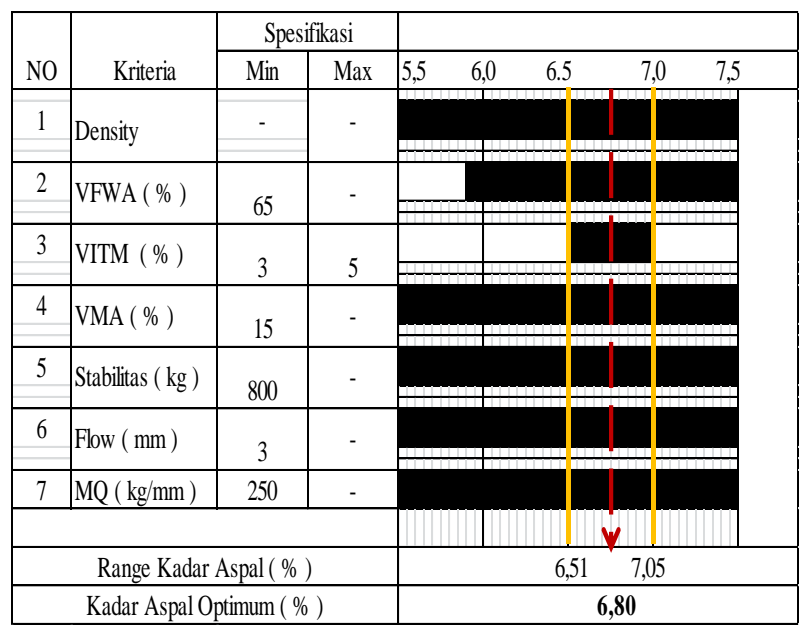

Gambar 4. Kadar aspal optimum (KAO) metode narrow range variasi 4 


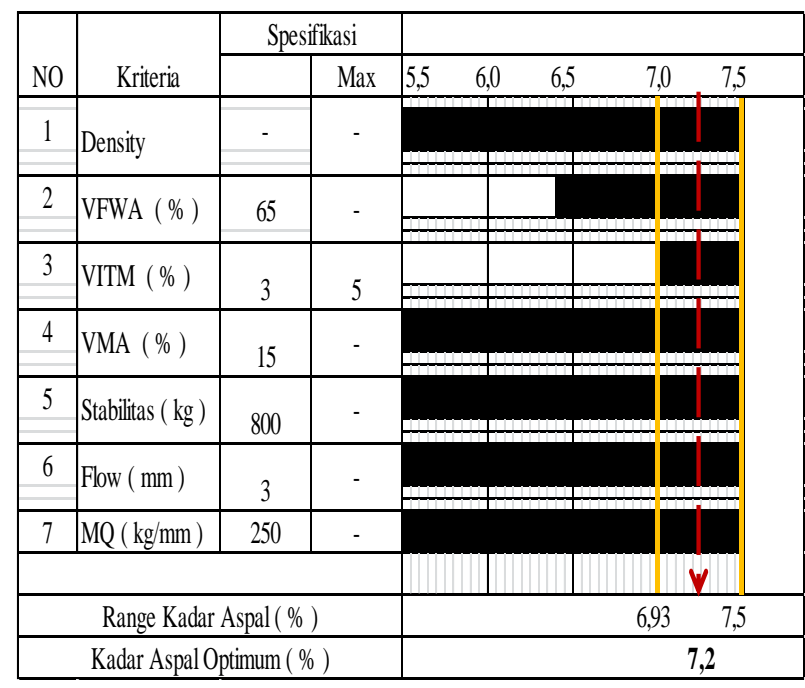

Gambar 5. Kadar aspal optimum (KAO) metode narrow range variasi 5

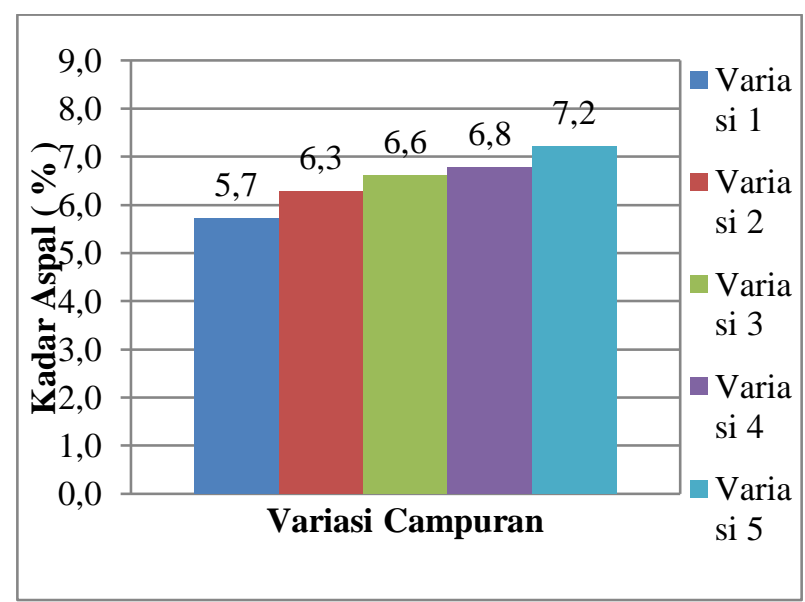

Gambar 6. (KAO) pada variasi campuran

\section{Analisis Karakteristik Campuran \\ Hubungan lama perendaman dengan nilai stabilitas}

Pengujian stabilitas dilakukan pada variasi lama perendaman 0 hari ( $0.5 \mathrm{jam}), 1$ (24 jam), 2 hari (48 jam) 4 hari (96 jam) dan 7 hari (168 jam), dengan 5 variasi campuran yaitu, variasi campuran 1 (100\% debu batu), variasi campuran 2 (75\% debu batu), variasi 3 ( $50 \%$ debu batu $-50 \%$ kapur padam), variasi 4 (75\% kapur padam) serta variasi 5 (100\% kapur padam). Grafik lama pengaruh perendaman terhadap nilai stabilitas ditunjukkan pada Gambar 7.

Dari gambar 7 dapat dilihat dari 5 variasi campuran yang dilakukan perendaman pada durasi waktu 0 hari, 24 jam, 48 jam, 96 jam dan 168 jam bahwa semakin lama dilakukan perendaman maka nilai stabilitas cenderung menurun. Turunnya nilai stabilitas tersebut disebabkan oleh air yang menembus pada lapisan agregat sehingga ketahanan lapisan aspal semakin berkurang. Setelah dilakukan perendaman pada 7 hari (168 jam), benda uji dengan $100 \%$ debu batu yaitu pada variasi campuran 1 memiliki nilai stabilitas $883 \mathrm{~kg}$ atau mengalami penurunan stabilitas sebesar $68,20 \%$ dari nilai stabilitas awal sebesar $1221 \mathrm{~kg}$, kemudian berturut-turut pada variasi campuran $75 \%$ debu batu yang memiliki nilai stabilitas $889 \mathrm{~kg}$ atau mengalami penurunan stabilitas sebesar $66,10 \%$ dari nilai stabilitas awal yaitu $1.346 \mathrm{~kg}$.

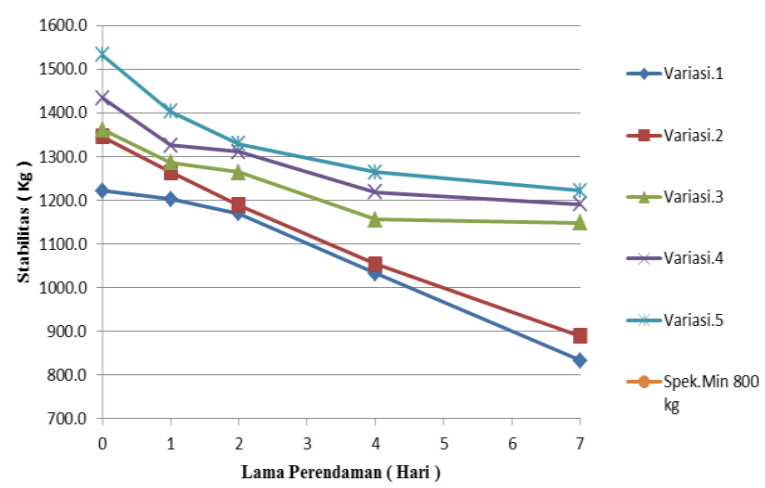

Gambar 7. Hubungan lama perendaman dengan nilai stabilitas

Seperti yang kita lihat pada Gambar 7. perbedaan terjadi pada beberapa variasi selanjutnya seperti pada variasi 3 , variasi 4 dan variasi 5 walaupun terjadi penurunan nilai stabilitas akan tetapi tidak terjadi penurunan yang signifikan terhadap nilai stabilitas awal yaitu untuk variasi 3 terjadi penurunan stabilitas sebesar $84,3 \%$ dari stabilitas awal, kemudian variasi 4 terjadi penurunan stabilitas sebesar $83,10 \%$ dari stabilitas awalnya, dan yang terakhir variasi 5 juga mengalami penurunan nilai stabilitas sebesar $79,70 \%$ terhadap nilai stabilitas awalnya yaitu 1533 $\mathrm{kg}$, sehingga untuk campuran 3 dan variasi campuran 4 yang memiliki variasi nilai stabilitas yang cukup ideal yang dihasilkan oleh penelitian ini karena penurunan stabilitasnya tidak secara signifikan.

\section{Hubungan lama perendaman dengan nilai pelelehan (flow)}

Nilai pelelehan atau (flow) dari semua variasi campuran berdasarkan hasil penelitian ini memenuhi persyaratan spesifikasi yaitu Min. $3 \mathrm{~mm}$, sebagai mana terlihat pada Gambar 8 .

Dari gambar 8 menunjukkan bahwa seiring dengan bertambahnya waktu perendaman, maka nilai flow juga cenderung mengalami kenaikan. Hal 
ini mengindikasikan bahwa campuran mudah terdeformasi akibat beban dan menjadi semakin plastis. Hal ini terjadi karena semakin lemahnya sifat kohesif antara aspal dan agregat.

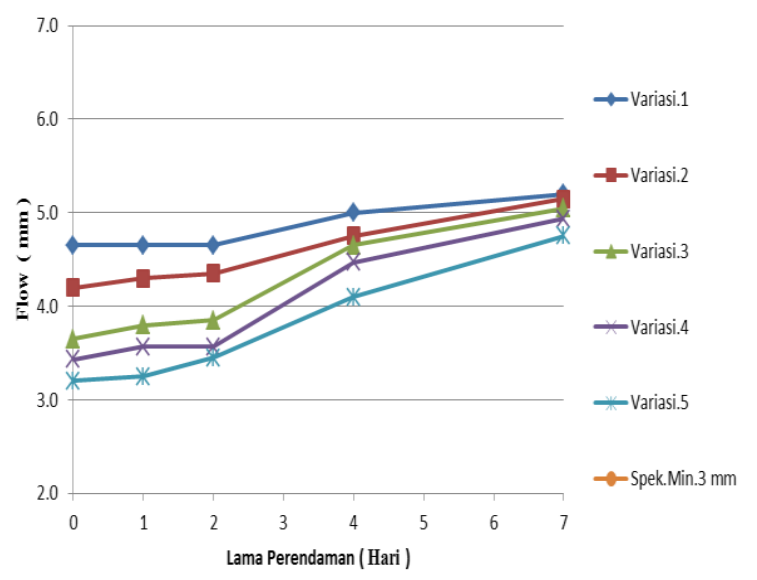

Gambar 8. Hubungan lama perendaman dengan nilai flow

Nilai flow menyatakan besarnya deformasi yang terjadi pada suatu lapis keras akibat beban lalu lintas. Suatu campuran dengan nilai flow tinggi akan cenderung lembek sehingga akan menyebabkan deformasi permanen apabila menerima beban. Sebaliknya jika nilai flow rendah maka campuran menjadi kaku dan mudah retak jika menerima beban yang mengalami daya dukungnya. Grafik nilai flow campuran $\mathrm{AC}-\mathrm{WC}$ untuk berbagai variasi kapur padam pada kadar aspal optimum. Nilai flow terendah ada pada variasi campuran 5 (100\% kapur padam) yakni $3.2 \mathrm{~mm}$, hal ini karena tingkat pemakaian kapur yang lebih dominan dalam campuran sampai $100 \%$ dari berat total filler. Akan tetapi dengan naiknya nilai flow akibat lama perendaman tidak mengakibatkan terjadinya deformasi permanen yang menyebabkan perkerasan aspal menjadi mudah retak apabila menerima beban dan daya dukung.

\section{Hubungan lama perendaman dengan nilai MQ (Marshall Qoutient)}

Nilai MQ atau (Marshall Qoutient) dari semua variasi campuran berdasarkan hasil penelitian ini sebagian saja yang memenuhi persyaratan spesifikasi yaitu Min. $250 \mathrm{~kg} / \mathrm{mm}$, sebagai mana terlihat pada Gambar 9.

Dari gambar 9. menunjukkan bahwa seiring dengan bertambahnya waktu perendaman, maka nilai Marshall Qoutient (MQ) cenderung mengalami penurunan. Seperti pada variasi campuran 5 (100\% kapur padam) yang merupakan nilai MQ tertinggi pada campuran Marshall normal (0 hari) akan tetapi setelah mengalami perendaman 24 jam, 48 jam, 96 jam dan 168 jam, rata-rata nilai MQ campuran langsung menurun secara signifikan, bahkan sampai berada di bawah batas dari spesifikasi yaitu Min. $250 \mathrm{~kg} / \mathrm{mm}$.

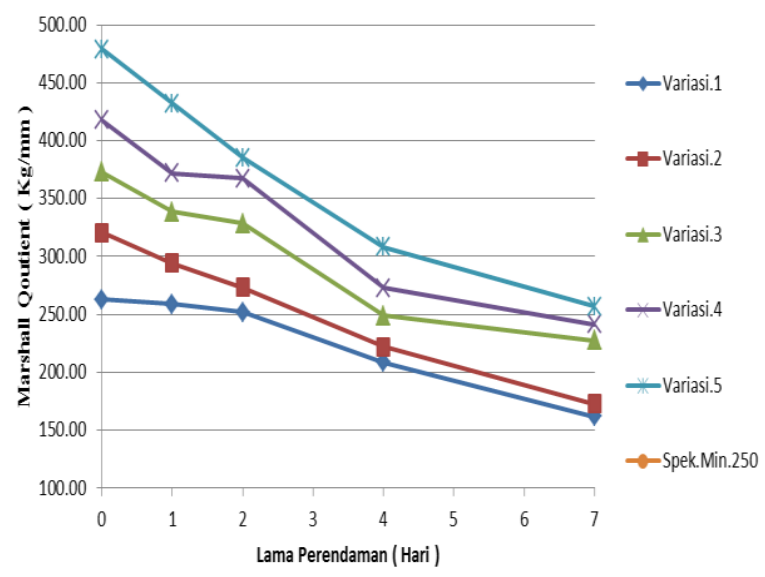

Gambar 9. Hubungan lama perendaman dengan nilai $M Q$.

Marshall Quotient adalah perbandingan antara stabilitas dan kelelehan yang juga merupakan indikator terhadap kekakuan campuran secara empiris. Semakin tinggi nilai MQ, maka kemungkinan akan semakin tinggi kekakuan satu campuran dan semakin rentan campuran tersebut terhadap keretakan. Namun nilai MQ ini juga tidak boleh terlalu rendah karena hal tersebut akan menyebabkan campuran rentan terhadap deformasi plastis.

\section{Retained Marshall Stability (RMS)}

Pada penelitian ini nilai Retained Marshall Stability (RMS) merupakan persentase perbandingan nilai stabilitas dengan lama perendaman standar $(0.5 \mathrm{jam})$ dengan nilai stabilitas lama perendaman 1 hari, 2 hari, 4 hari dan 7 hari. Hasil yang diperoleh dari perendaman tersebut untuk beberapa variasi campuran seperti pada variasi $1(100 \%$ debu batu) yaitu berturut-turut $100 \%, 98,5 \%, 95,8 \%, 89,5 \%$ dan $68.2 \%$, kemudian pada variasi $2(75 \%$ debu batu) yaitu berturut-turut $100 \%, 93,9 \%, 88,3 \%, 78,3 \%$ dan $66,1 \%$, pada variasi 3 (50\% debu batu $-50 \%$ kapur padam) yaitu berturut-turut $100 \%, 94,4 \%, 92,9 \%, 84,9 \%$ dan $84,3 \%$ kemudian pada variasi 4 (75\% kapur padam) yaitu berturut-turut $100 \%, 92,5 \%, 91,5 \%, 85,0 \%$ dan $83,1 \%$ dan variasi 5 (100\% kapur padam) yaitu $100 \%, 91,6 \%, 91,5 \%, 82,5 \%$ dan 79,7\% . Grafik RMS ditunjukkan pada Gambar 10. 


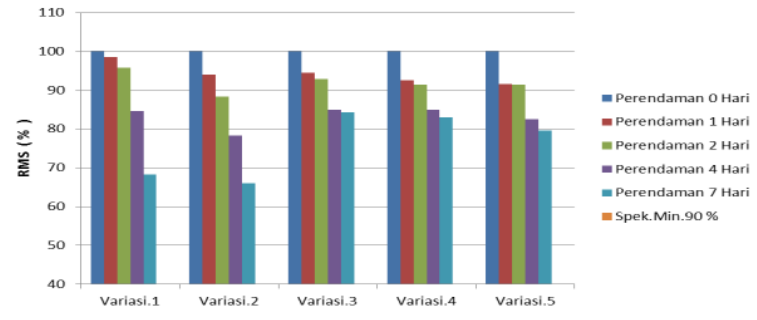

Gambar 10. Hubungan lama perendaman dengan nilai RMS

\section{Analisis Indeks Penurunan Stabilitas}

Penurunan stabilitas campuran terjadi seiring dengan dilakukannya perendaman, hal ini terjadi akibat menurunnya kerekatan antara aspal dan agregat yang disebabkan oleh air. Nilai indeks stabilitas di pengaruhi oleh parameter menurunnya keawetan campuran $(\mathrm{r} \%)$ dan juga menurunnya kekuatan campuran $(\mathrm{a} \%)$.

\section{Indeks durabilitas pertama (IDP)}

Dari hasil penelitian didapatkan nilai Indeks Durabilitas Pertama (IDR) yaitu (r\%) yang bernilai positif $(+)$. Nilai positif ini menunjukkan bahwa benda uji mengalami kehilangan kekuatan dalam satuan persen. Pada penelitian ini menunjukkan bahwa dari beberapa variasi campuran mengalami kehilangan kekuatan yang bervariatif, mulai dari campuran variasi 1 (100\% debu batu) mengalami kehilangan kekuatan (r) total sebesar $0,64 \%$, dan campuran variasi 2 (75\% debu batu) dengan (r) total $0,87 \%$, campuran variasi 3 (50\% kapur padam) dengan (r) total $0,48 \%$ dan campuran variasi $4(75 \%$ kapur padam) dengan (r) total $0,52 \%$, kemudian campuran variasi 5 (100\% kapur padam) dengan total kehilangan kekuatan (r) total sebesar $0,69 \%$. Dengan demikian maka campuran variasi $3(50 \%$ kapur padam $-50 \%$ debu batu ) dengan persentase kehilangan kekuatan yang terkecil yakni $0,48 \%$ dimana perpaduan antara kapur padam dan debu batu mampu memperkecil pengaruh penurunan kekuatan secara berurutan yakni $0,48 \%, 0,52 \%$, $0,64 \%, 0,69 \%$ dan $0,87 \%$ serta merupakan formula ideal dan paling tahan terhadap pengaruh air pada durabilitas pertama. Seperti pada Tabel 6 .

Tabel 6. Indeks durabilitas pertama (IDP) dan (IDK)

\begin{tabular}{|c|c|c|c|c|c|c|c|c|c|}
\hline \multirow[t]{2}{*}{ No } & \multirow{2}{*}{$\begin{array}{c}\text { Variasi } \\
\text { Campur } \\
\text { an }\end{array}$} & \multirow{2}{*}{$\begin{array}{l}\text { Marshall } \\
\text { Stabilitas } \\
\text { Awal (Kg) }\end{array}$} & \multirow{2}{*}{$\begin{array}{c}\text { Indek } \\
\text { Kekuatan } \\
\text { Sisa (\%) } \\
\text { (IKS) }\end{array}$} & \multicolumn{2}{|c|}{$\begin{array}{c}\text { Indeks } \\
\text { Durabilitas } \\
\text { Pertama (IDP) }\end{array}$} & \multicolumn{4}{|c|}{ Indeks Durabilitas Kedua (IDK) } \\
\hline & & & & $\begin{array}{c}r \\
(\%)\end{array}$ & $\mathrm{R}(\mathrm{Kg})$ & $\begin{array}{c}a \\
(\%)\end{array}$ & $A(K g)$ & $\begin{array}{l}\text { sa } \\
(\%)\end{array}$ & $\begin{array}{l}\text { Sa } \\
(\mathbf{K g})\end{array}$ \\
\hline 1 & Variasi.1 & 1.221 .27 & 98.49 & 0.64 & 7.79 & 21.6 & 205.18 & 78.4 & 957.3 \\
\hline 2 & Variasi.2 & 1.346 .01 & 93.94 & 0.87 & 11.7 & 24.5 & 261.62 & 75.5 & 1016.3 \\
\hline 3 & Variasi.3 & 1.361 .77 & 94.44 & 0.48 & 6.48 & 11.4 & 139.45 & 88.6 & 1207.0 \\
\hline 4 & Variasi.4 & 1.433 .82 & 92.49 & 0.52 & 7.51 & 12.9 & 164.59 & 87.1 & 1249.4 \\
\hline 5 & Variasi.5 & 1.533 .00 & 91.57 & 0.69 & 10.55 & 16.1 & 215.76 & 83.9 & 1286.6 \\
\hline
\end{tabular}

Dengan demikian maka campuran variasi 3 yaitu $50 \%$ debu batu dan 50\% kapur padam, dengan persentase kehilangan kekuatan yang terkecil yakni $0,48 \%$ dimana perpaduan antara kapur padam dan debu batu mampu memperkecil pengaruh penurunan kekuatan secara berurutan yakni $0,48 \%, 0,52 \%, 0,64 \%, 0,69 \%$ dan $0,87 \%$ serta merupakan formula ideal dan paling tahan terhadap pengaruh air pada durabilitas pertama.

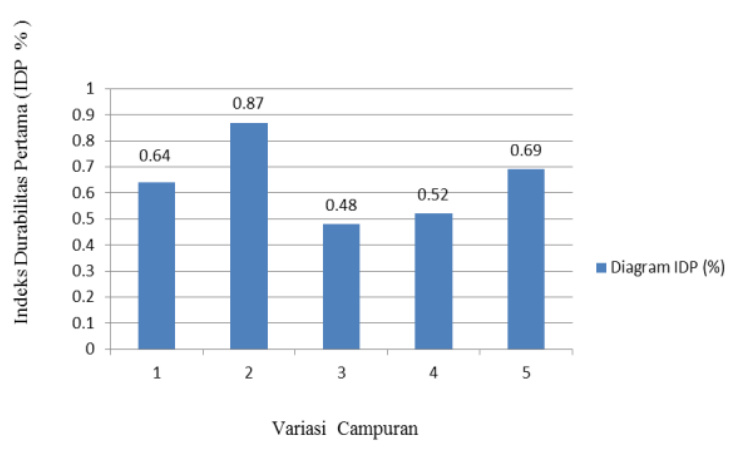

Gambar 11. Indeks Durabilitas Pertama (IDP) 


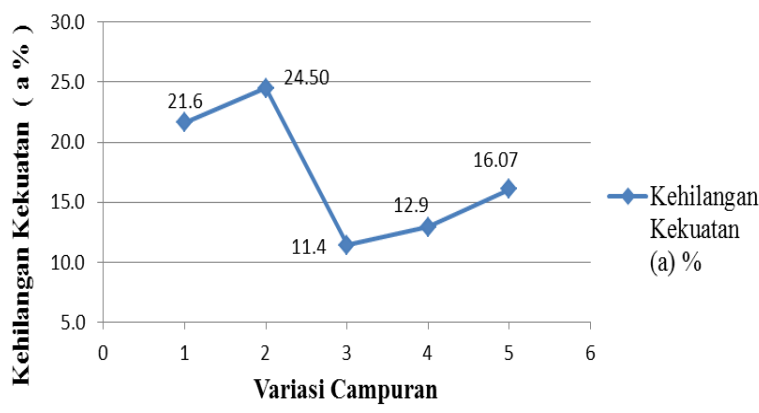

Gambar 12. Pengaruh Variasi Campuran Terhadap Kehilangan Kekuatan

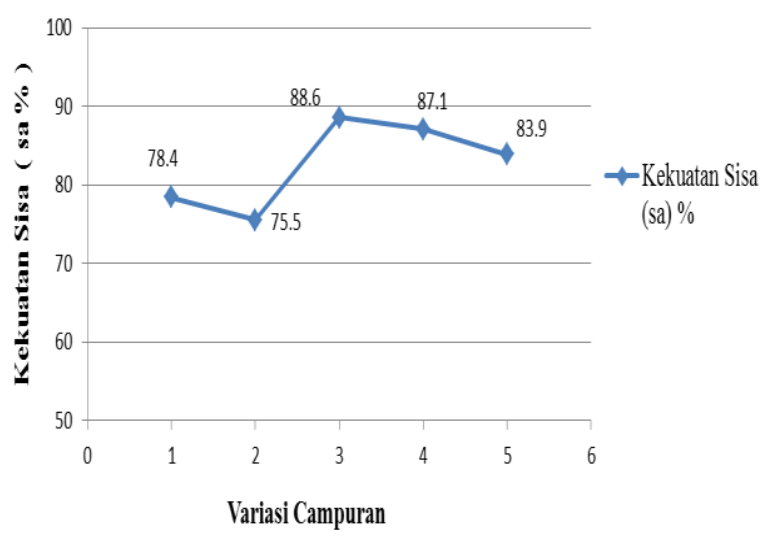

Gambar 13. Pengaruh Variasi Campuran Terhadap Kekuatan Sisa

\section{Indeks durabilitas kedua (IDK)}

Dari hasil penelitian seperti yang terlihat pada Tabel 6. didapatkan nilai indeks durabilitas kedua (IDK) pada penelitian ini menunjukkan nilai (a \% ) total dari benda uji pada campuran variasi $1(100 \%$ debu batu) dengan (a) total sebesar 21,6\%, dan campuran variasi 2 (75\% debu batu) dengan (a) total $24,5 \%$, campuran variasi $3 \quad(50 \%$ kapur padam) dengan (a) total $11,4 \%$ dan campuran variasi 4 (75\% kapur padam) dengan (a) total $12,9 \%$, kemudian campuran variasi 5 (100\% kapur padam) dengan total kehilangan kekuatan (a) total sebesar 16,1\%. Terlihat bahwa pengaruh perendaman terhadap campuran dapat menurunkan nilai (a) atau kehilangan kekuatan dan sebaliknya akan menaikan nilai stabilitas sisa (sa), dari beberapa variasi campuran terlihat bahwa terjadi kehilangan kekuatan yang terkecil adalah pada campuran variasi 3 yaitu sebesar $11,4 \%$ dengan mengunakan bahan pengisi filler $50 \%$ kapur padam $-50 \%$ debu batu serta merupakan bahan campuran paling tahan terhadap pengaruh air.
Tabel 7. Nilai durabilitas berdasarkan RMS (campuran variasi 1)

\begin{tabular}{cccc}
\hline Kode & $\begin{array}{c}\text { Luas area } \\
\left(\mathbf{C m}^{\mathbf{2}}\right)\end{array}$ & $\begin{array}{c}\text { Perendaman } \\
\text { (hari) }\end{array}$ & $\begin{array}{c}\text { Indeks } \\
\text { durabilitas } \\
\mathbf{( \% )}\end{array}$ \\
\hline $\mathrm{A} 1$ & 16,89 & 1 & 1,4 \\
\hline $\mathrm{A} 2$ & 24,74 & 2 & 2,11 \\
\hline $\mathrm{A} 3$ & 66,41 & 4 & 6,43 \\
\hline $\mathrm{A} 4$ & 97,15 & 7 & 11,66 \\
\hline \multicolumn{5}{c}{ Total indeks durabilitas } \\
\hline \multicolumn{5}{c}{}
\end{tabular}

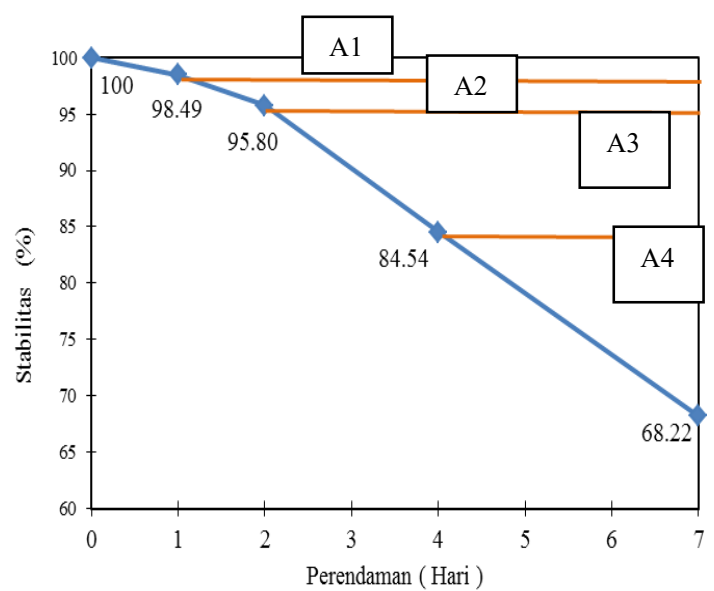

Gambar 14. Durabilitas dalam pengujian variasi 1

Dari Gambar 14 dan Tabel 7 diperoleh nilai indeks durabilitas berdasarkan RMS untuk benda uji campuran variasi 1 (100\% debu batu) sebesar $21.6 \%$, ini berarti nilai indeks durabilitas pada jenis campuran ini cukup besar jika dibandingkan dengan jenis campuran yang lainya dan kurang tahan terhadap pengaruh air akibat rendaman selama 7 hari (168 jam).

Tabel 8. Nilai durabilitas berdasarkan RMS (campuran variasi 2)

\begin{tabular}{cccc}
\hline Kode & $\begin{array}{c}\text { Luas area } \\
\left(\mathbf{C m}^{\mathbf{2}}\right)\end{array}$ & $\begin{array}{c}\text { Perendaman } \\
\text { (hari) }\end{array}$ & $\begin{array}{c}\text { Indeks } \\
\text { durabilitas } \\
\mathbf{( \% )}\end{array}$ \\
\hline A1 & 71,10 & 1 & 5,62 \\
\hline A2 & 52,50 & 2 & 4,42 \\
\hline A3 & 60,44 & 4 & 5,74 \\
\hline A4 & 77,58 & 7 & 8,72 \\
\hline \multicolumn{3}{c}{ Total indeks durabilitas } \\
\hline
\end{tabular}




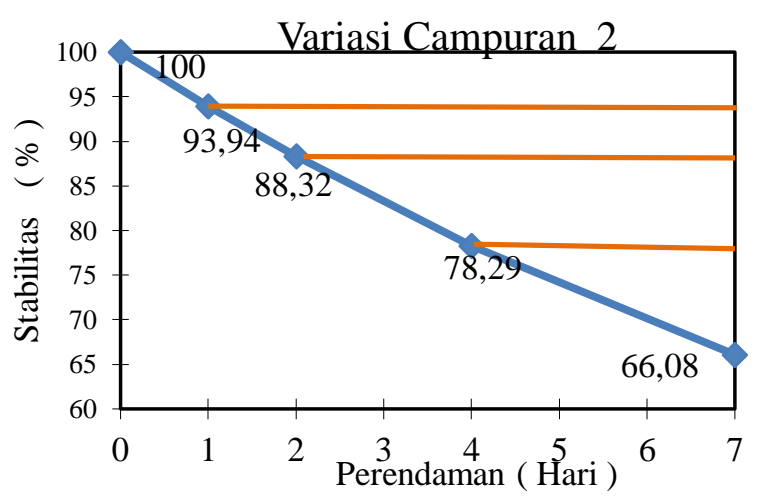

Gambar 15. Durabilitas dalam pengujian variasi 2

Dari Gambar 15 dan Tabel 8 diperoleh nilai indeks durabilitas berdasarkan RMS untuk benda uji campuran variasi 2 (75\% debu batu) sebesar $24,5 \%$. Pada jenis campuran ini dimana menggunakan $75 \%$ debu batu - $25 \%$ kapur padam adalah campuran yang memiliki indeks durabilitas yang terbesar dari beberapa variasi campuran lainya yaitu sebesar $24,5 \%$, hal ini berarti pemanfaatan filler yang didominasi oleh debu batu akan menjadikan campuran kurang tahan terhadap pengaruh perendaman dalam waktu yang lama yaitu dilakukan perendaman selama 7 hari (168 jam).

Gambar 16. Tabel 5.9. Nilai durabilitas (campuran variasi 3)

\begin{tabular}{cccc}
\hline Kode & $\begin{array}{c}\text { Luas } \\
\text { area } \\
\left(\mathbf{C m}^{\mathbf{2}}\right)\end{array}$ & $\begin{array}{c}\text { Perendaman } \\
\text { (hari) }\end{array}$ & $\begin{array}{c}\text { Indeks } \\
\text { durabilitas } \\
\mathbf{( \% )}\end{array}$ \\
\hline $\mathrm{A} 1$ & 66,35 & 1 & 5,16 \\
\hline $\mathrm{A} 2$ & 15,77 & 2 & 1,25 \\
\hline $\mathrm{A} 3$ & 52,45 & 4 & 4,54 \\
\hline $\mathrm{A} 4$ & 4,88 & 7 & 0,43 \\
\hline \multicolumn{4}{c}{ Total indeks durabilitas } \\
\hline
\end{tabular}

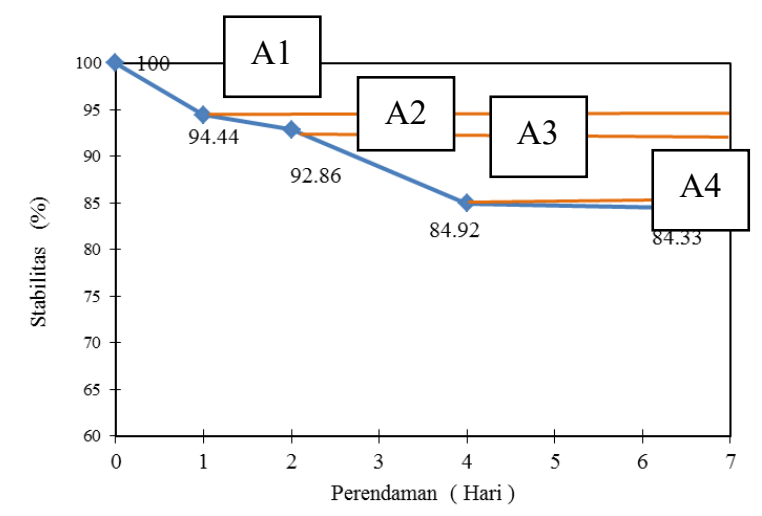

Gambar 17. Durabilitas dalam pengujian variasi 3
Dari Gambar 16 dan Tabel 9. diperoleh nilai indeks durabilitas berdasarkan RMS untuk benda uji campuran variasi 3 (50\% debu batu $-50 \%$ kapur padam) sebesar 11,4\%. Berdasarkan hasil penelitian yang ditunjukkan dalam Tabel 20, bahwa jenis variasi campuran ini memiliki nilai indeks durabilitas yang terkecil yakni 11,4\% baik pada indeks durabilitas pertama (IDP), maupun nilai indeks durabilitas kedua (IDK) hal ini berarti bahwa campuran dengan variasi 3 yaitu $50 \%$ debu batu - 50\% kapur padam memiliki durabilitas lebih baik jika melalui suatu proses perendaman campuran dalam waktu lama.

Gambar 18. Nilai durabilitas berdasarkan RMS (campuran variasi 4)

\begin{tabular}{cccc}
\hline Kode & $\begin{array}{c}\text { Luas } \\
\text { area } \\
\left(\mathbf{C m}^{\mathbf{2}}\right)\end{array}$ & $\begin{array}{c}\text { Perendaman } \\
\text { (hari) }\end{array}$ & $\begin{array}{c}\text { Indeks } \\
\text { durabilitas } \\
\mathbf{( \% )}\end{array}$ \\
\hline $\mathrm{A} 1$ & 92,44 & 1 & 6,97 \\
\hline $\mathrm{A} 2$ & 10,68 & 2 & 0,81 \\
\hline $\mathrm{A} 3$ & 44,95 & 4 & 3,69 \\
\hline A4 & 16,52 & 7 & 1,39 \\
\hline \multicolumn{3}{r}{ Total indeks durabilitas } \\
\hline
\end{tabular}

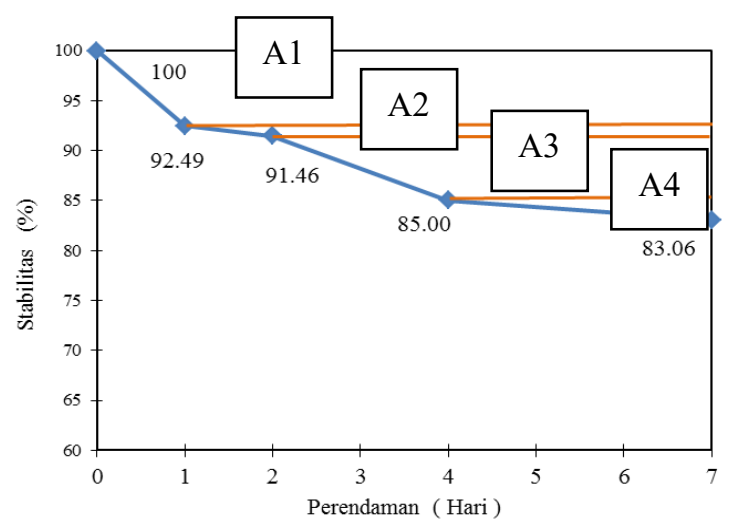

Gambar 19. Durabilitas dalam pengujian variasi 4

Dari Gambar 17 dan Tabel 10 diperoleh nilai indeks durabilitas berdasarkan RMS untuk benda uji campuran variasi 4 (75\% kapur padam - 25\% debu batu) sebesar $12,90 \%$. Dari hasil penelitian ini untuk jenis campuran variasi 4 , merupakan salah satu campuran yang memiliki nilai indeks durabilitas terkecil setelah campuran pada variasi 3 , ini menunjukkan bahwa jenis variasi campuran $75 \%$ penggunaan kapur padam dan $25 \%$ debu batu pada total kebutuhan filler masih sangat baik untuk 
digunakan pada campuran perkerasan $\mathrm{AC}-\mathrm{WC}$ yang mengalami perendaman dalam waktu yang cukup lama.

Gambar 20. Nilai durabilitas berdasarkan RMS (campuran variasi 5)

\begin{tabular}{cccc}
\hline Kode & $\begin{array}{c}\text { Luas } \\
\text { area } \\
\left(\mathbf{C m}^{\mathbf{2}}\right)\end{array}$ & $\begin{array}{c}\text { Perendaman } \\
\text { (hari) }\end{array}$ & $\begin{array}{c}\text { Indeks } \\
\text { durabilitas } \\
\mathbf{( \% )}\end{array}$ \\
\hline A1 & 109,89 & 1 & 7,83 \\
\hline A2 & 50,70 & 2 & 3,81 \\
\hline A3 & 30,50 & 4 & 2,42 \\
\hline A4 & 24,60 & 7 & 2,01 \\
\hline \multicolumn{4}{c}{ Total indeks durabilitas } \\
\hline
\end{tabular}

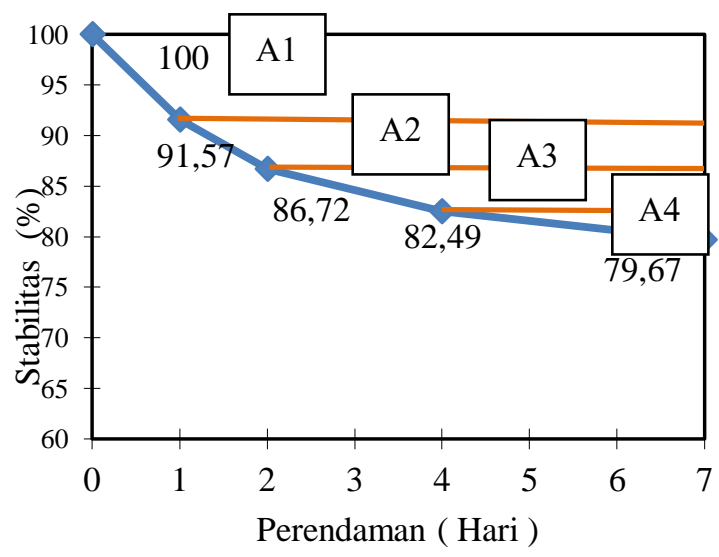

Gambar 21. Durabilitas dalam pengujian variasi 5

Dari Gambar 18 dan Tabel 11, diperoleh nilai indeks durabilitas berdasarkan RMS untuk benda uji campuran variasi 5 (100\% kapur padam) sebesar $16.07 \%$. Pada jenis variasi campuran ini merupakan urutan ke 3 yang mempunyai nilai indeks durabilitas terkecil setelah variasi ke 3 dan variasi ke 4. Dengan indeks durabilitas $16,07 \%$ seperti penggunaan $100 \%$ kapur padam dalam total persentase kebutuhan filler dalam campuran mengindikasikan bahwa penggunaan bahan kapur padam yang diantaranya berfungsi sebagai bahan pengisi pada campuran akan mampu mempertahankan nilai stabilitas dan durabilitas pada perkerasan aspal AC-WC.

Dari hasil analisis dari 5 variasi campuran, maka dapat disimpulkan bahwa dengan pemanfaatan bahan alam kapur padam dan debu batu antara $50 \%$ sampai $75 \%$ pada total kebutuhan persentase filler, masih sangat baik untuk mempertahankan nilai stabilitas dan durabilitas campuran yang mengalami perendaman dalam waktu lama.

\section{KESIMPULAN DAN SARAN Kesimpulan}

Dari hasil penelitian pemanfaatan agregat sungai (debu batu dan kapur padam) sebagai filler yang ada di Kabupaten Tolitoli Provinsi Sulawesi Tengah terhadap pengaruh stabilitas dan durabilitas pada campuran aspal panas AC-WC gradasi halus dengan Menggunakan aspal Pertamina Pen. 60/70, di Laboratorium Teknik Transportasi Universitas Gadjah Mada dapat diambil beberapa kesimpulan berikut.

Komposisi campuran variasi 1 yang menggunakan $100 \%$ debu batu - $0 \%$ kapur padam, dengan kadar aspal optimum (KAO) sebesar 5,7\%. Campuran Variasi 2 yang menggunakan $75 \%$ debu batu - 25\% kapur padam, dengan KAO 6,3\%. Campuran variasi 3 yang menggunakan 50\% debu batu $-50 \%$ kapur padam, dengan KAO 6,6\%. Campuran variasi 4 yang menggunakan $75 \%$ kapur padam - 25\% debu, dengan KAO 6,8\%. Serta campuran variasi 5 yang menggunakan $100 \%$ kapur padam, dengan KAO 7,2\%

Karakteristik Marshall dari semua variasi campuran pada kondisi kadar aspal optimum KAO, yaitu untuk variasi 1, Campuran ini memiliki nilai stabilitas awal $1221 \mathrm{~kg}$, dan pelelehan (flow) 4,7 mm (Spesifikasi Min. 3), nilai Marshall Qoutient $263 \mathrm{~kg} / \mathrm{mm}$. (Spesifikasi Min. 250). Campuran variasi 2 dengan nilai stabilitas awal $1346 \mathrm{~kg}$, pelelehan (flow) 4,2 mm, dan Marshall Qoutient $320 \mathrm{~kg} / \mathrm{mm}$. Campuran variasi 3 dengan nilai stabilitas awal $1362 \mathrm{~kg}$, dan pelelehan (flow) 3,7 $\mathrm{mm}$, dan nilai Marshall Qoutient $370 \mathrm{~kg} / \mathrm{mm}$. Campuran variasi 4 dengan nilai stabilitas awal $1434 \mathrm{~kg}$, dan nilai pelelehan (flow) $3,4 \mathrm{~mm}$ serta nilai Marshall Qoutient $418 \mathrm{~kg} / \mathrm{mm}$. Kemudian campuran variasi 5 dengan nilai stabilitas awal $1533 \mathrm{~kg}$, pelelehan 3,2 serta nilai Marshall Qoutient $479 \mathrm{~kg} / \mathrm{mm}$. Sehingga pada dasarnya menurut kriteria dan parameter angka kekuatan dan kekakuan, serta fleksibilitas, semua variasi campuran memenuhi persyaratan dari Spesifikasi Kementerian Pekerjaan Umum tahun 2010 (Rev.2). Komposisi campuran tersebut dapat digunakan sebagai campuran pada perkerasan aspal AC-WC, gradasi halus.

Tingkat keawetan campuran (durabilitas) dan ketahanan campuran terhadap pengaruh air pada kondisi $\mathrm{KAO}$, setelah mengalami serangkaian periode perendaman (Immersion), pada durasi 1 hari (24 jam), 2 hari (48 jam), 4 hari (96 jam), serta 
7 hari (168 jam) Berdasarkan hasil analisa bahwa variasi campuran 3 dengan $50 \%$ kapur padam $50 \%$ debu batu, adalah merupakan campuran yang memiliki nilai durabilitas terbaik, kemudian variasi campuran 4 dengan $75 \%$ kapur padam $-25 \%$ debu batu, berdasarkan parameter indeks kekuatan sisa atau Retained Marshall Stability (RMS), maupun indeks durabilitas pertama (IDP) dan indeks durabilitas kedua (IDK).

Nilai indeks kekuatan sisa (IKS) dan nilai indeks durabilitas dari variasi campuran 3 , adalah untuk nilai IKS yaitu 94,4\% lebih besar dari spesifikasi Min. 90\%, bahkan setelah mengalami periode perendaman selama 7 hari (168 jam) memiliki nilai stabilitas $1148 \mathrm{~kg}$, lebih besar dari $800 \mathrm{~kg}$ (Spesifikasi Min. $800 \mathrm{~kg}$ ). Berdasarkan IDP campuran ini memiliki indeks durabilitas terkecil yakni $0,48 \%$ sehingga dikategorikan sebagai campuran yang mempunyai nilai kehilangan keawetan (r) yang terkecil. Kemudian untuk variabel IDK campuran ini mempunyai nilai kehilangan kekuatan (a) sebesar 11,4\% kemudian sebaliknya memiliki indeks kekuatan sisa (sa) $88,6 \%$.

Kriteria tingkat keawetan campuran setelah mengalami periode perendaman (Immersion), yaitu pada variasi campuran 4 merupakan salah satu jenis campuran yang memenuhi syarat terbaik kedua, setelah variasi campuran 3 untuk nilai durabilitas yang cukup baik berdasarkan parameter Retained Marshall Stability (RMS) maupun indeks durabilitas pertama (IDP) dan indeks durabilitas kedua (IDK).

Variasi campuran 4 yang menggunakan $75 \%$ kapur padam - $25 \%$ debu batu, juga memenuhi beberapa kriteria antara lain yaitu, pemanfaatan bahan pengisi alami seperti kapur padam yang lebih dominan bahkan sampai $75 \%$ dari total kebutuhan akan bahan pengisi filler, tentu hal ini sangat bernilai ekonomis, karena pengelolaannya sangat sederhana, serta dapat juga memenuhi kebutuhan akan filler dalam jumlah yang cukup, yang selama ini menjadi masaalah serta mempunyai deposit bahan yang cukup tersedia di Daerah Sulawesi Tengah.

\section{Saran}

Beberapa saran yang dapat disampaikan untuk penyempurnaan hasil penelitian tentang studi potensi pemanfaatan agregat sungai di Kabupaten Tolitoli Provinsi Sulawesi Tengah, dengan kapur padam dan debu batu sebagai filler terhadap stabilitas dan durabilitas pada campuran aspal ACWC berikut.

Masih perlu adanya penelitian lanjutan mengenai pengaruh pemanfaatan agregat sungai di Kabupaten Tolitoli terhadap jenis perkerasan aspal lainya seperti AC-BC, HRS-WC dan HRS-BC, terutama untuk dapat melayani beban kondisi lalu lintas berat sebagai pendekatan kondisi lapangan.

Perlu penelitian lanjutan mengenai proses perencanaan campuran aspal AC-BC, HRS-BC, dengan pemanfaatan (pasir alam) sebagai agregat halus dengan persentase penggunaan lebih besar dari $20 \%$ terhadap campuran yang juga memiliki deposit yang sangat melimpah di Kabupaten Tolitoli.

Melakukan penelitian dengan menggunakan jenis bahan filler yang berbeda, seperti pemanfaatan jenis filler dari debu sekam padi dan debu sekam kayu olahan yang sangat banyak dan melimpah di Kabupaten Tolitoli, yang tujuannya untuk melihat perbandingan karakteristik campuran yang dihasilkan.

\section{DAFTAR PUSTAKA}

[1] Brown E, Kandhal PS, Roberts FL, et al. (2009) Hot mix asphalt materials, mixture design, and construction. USA.

[2] Roberts FL, Kandhal PS, Brown ER, et al. (1991) Hot mix asphalt materials, mixture design and construction.

[3] Sukirman S (1999) Perkerasan lentur jalan raya. Bandung: Nova.

[4] Institute A (1983) Asphalt Cold-Mix Recycling: Asphalt Institute.

[5] Wibowo J (2018) Analisis Desain Perkerasan Jalan Metode Bina Marga 1987 Bina Marga 2002 Dan Evaluasi Struktur Perkerasan Jalan (Ruas Pelebaran Jalan Bantal-Mukomuko Bengkulu): Universitas Muhammadiyah Surakarta.

[6] Sukarman S (2003) Beton Aspal Campuran Panas: Yayasan Obor Indonesia. ISBN: 9794614726.

[7] Marga KPUDJB (2013) Manual Desain Perkerasan Jalan.

[8] AASHTO M (1998) Standard specification for performance-graded asphalt binder: American Association of State Highway Transportation Officials.

[9] Domel II, Sentosa L (2014) Penggunaan Pasir Alam Dalam Campuran Beraspal jenis AC-WC Dengan Pengujian Marshall Berdasarkan Sfesifikasi Bina Marga Tahun 2010. Jurnal Online Mahasiswa Fakultas Teknik Universitas Riau Vol. 1, No. 1: hal. 1-8.

[10] Ashley K, Schlecht PC, Song R, et al. (1996) ASTM Sampling methods and analytical validation for lead in paint, dust, soil, and air. Sampling Environmental Media: ASTM International. 
[11] Miller JS, Uzan J, Witczak MW (1983) Modification Of The Asphalt Institute Bituminous Mix Modulus Predictive Equation (Discussion). ISBN: 0309035546.

[12] Suparma LB (2004) The Mix Ageing Behaviour of The Asphaltic Concrete (AC) Mixture Containing Recycled Plastics Waste Aggregate Replacement (Ac-Plastiphalt). Media Teknik Vol. 26, No. 2004.

[13] Bahia HU, Hanson D, Zeng M, et al. (2001) Characterization of modified asphalt binders in superpave mix design. ISBN: 0309067073.

[14] Rahim A, Wihardi M, Muhiddin AB, et al. (2012) Pengaruh Air Laut terhadap Karakteristik Perkerasan Aspal Porus yang Menggunakan Asbuton sebagai Bahan Pengikat.

[15] Edison B (2014) Karakteristik Campuran Aspal Panas (Asphalt Concrete-Binder Course) Menggunakan Aspal Polimer. Jurnal Aptek Vol. 2, No. 1: hal. 60-71.

[16] Marga DJB (2010) Spesifikasi Umum Bidang Jalan dan Jembatan Divisi 6 Perkerasan Beraspal. Bandung: Pusat Litbang Jalan dan Jembatan Badan Penelitian dan Pengembangan.

(C) 2019 the Author(s), licensee Jurnal LINEARS. This is an open access article distributed under the terms of the Creative Commons Attribution License

(http://creativecommons.org/licenses/by/4.0) 